\title{
Mangifera Indica Solvent Fractions: A Treatment for Iron Deficiency Anaemia Induced by Diet in Albino Rats
}

\author{
Abidakun $\mathrm{OM}^{1 *}$, Modupe $\mathbf{0}^{1,2}$ and Oladiji $\mathrm{AT}^{1}$ \\ ${ }^{1}$ Nutritional Biochemistry Laboratory, University of Ilorin, Nigeria \\ ${ }^{2}$ University of Toronto, Canada
}

Submission: February 03, 2017; Published: August 17, 2018

*Corresponding author: Abidakun, Oreoluwa Moyosore, Nutritional Biochemistry Laboratory, University of Ilorin, Nigeria, Tel: +2348061334928; Email: Oreoluwa.abidakun@gmail.com

\begin{abstract}
Iron deficiency is a micronutrient deficiency which is common in the developing regions of the world. Mangifera indica is one of the plants used traditionally in the treatment of iron deficiency anaemia especially in the South Western region of Nigeria. This study was carried out to determine the bioactive agent found in Mangifera indica responsible for its anti-anaemic action.

40 (forty) albino rats were used for the experiment, the iron deficient group were fed with an iron deficient feed for 8weeks, this induced iron deficiency anaemia. The stem bark of Mangifera indica was pulverized, extracted with ethanol and subsequently with n-hexane and ethyl acetate solvents, these fractions were then concentrated using a rotary evaporator, the fractions were screened for the phytochemicals present. The iron deficient animals were administered with $1 \mathrm{ml}$ of the ethyl acetate, $\mathrm{n}$-hexane and ethanolic solvent fractions dissolved in distilled water for 2 weeks.
\end{abstract}

The results showed significant $(\mathrm{P}<0.05)$ increase in the $\mathrm{PCV}, \mathrm{RBC}$ and the serum ferritin level of the groups administered with the extracts when compared with the iron sufficient and iron deficient control groups and saponins were found to be present in the three extract fractions.

It was concluded that saponins might be the bioactive agent responsible for the heamotopoietic action of Mangifera indica by acting either as a facilitator in diffusion of iron for absorption or making iron readily available for absorption as an antioxidant..

Keywords: Micronutrient Malnutrition; Haemoglobin; Iron deficiency; Anaemia; Mangifera indica; Saponins; Serum Ferritin

Abbreviations: MNM: Micronutrient Malnutrition; EA: Ethyl Acetate; NH: Hexane; ET: Ethanolic; ELISA: Enzyme-Based Immunosorbent Assay; SEM: Standard Error of Mean; PCV: Packed Cell Volume; RCB: Red Blood Cell; MCH: Mean Cell Haemoglobin; MCHC: Mean Cell Haemoglobin Concentration

\section{Introduction}

Iron, a trace element, is an important cofactor in some cellular functions such as oxygen transport, energy metabolism and DNA synthesis [1]. Due to its importance, a deviation from its normal status is often hazardous to cells, a rise in status leads to iron toxicity that causes oxidative stress; a fall in its status causes iron deficiency, a major cause of anaemia. Both cases if not properly managed can eventually lead to death.

Iron deficiency is a form of micronutrient malnutrition (MNM), and is the most prevalent MNM [2]. It has high prevalence in developing regions of the world; children and pregnant women been mostly affected, and this sets in upon continuous feeding on an iron deficient diet for a period of time. Iron deficiency leads to anaemia which manifests as a condition in which the number of red blood cells or their oxygen-carrying capacity is not sufficient to meet the physiologic needs, it develops when the rate of red cell production fails to keep pace with destruction or loss of cells [3]. The effects of iron deficiency are aggravated by poverty and lack of hygiene [4] . Other conditions such as nutritional deficiencies (vitamin B12, folate etc), parasitic gastrointestinal infections, malaria and haemoglobinopathies are also known to cause anaemia $[5,6]$.

Ferritin is a protein produced in the body which functions in iron storage, making iron unavailable for invading pathogenic organisms and withholds free iron from causing damage to the cells. Serum ferritin is a biomarker used in the detection of mild iron deficiency. Serum ferritin assay has been reported to be the most sensitive assay and readily available method for the assessment of iron stores and mild iron depletion detection [7].

In developing countries such as Nigeria, people depend on medicinal plants for treatment of diseases due to its affordability and availability [8]. Some of the plants have been found to be efficacious in treatment of several diseases due to bioactive 
agents (chemical substances) present in the plants in the form of phytochemicals and minerals [9]. This knowledge led to the use of Mangifera indica (mango) for the treatment of anaemia as reported by folklore and has been confirmed by scientific studies $[10,11]$.

Mangifera indica (mango) is one of the most important tropical plants and it is widely grown in different parts of Africa especially the southern part of Nigeria [10]. Its stem bark, roots and leaves have been reported to be efficacious in the treatment of malaria, diabetes, asthma and anaemia [11,12]. This study was carried out to investigate the efficacy of Mangifera indica solvent fractions as anti-anaemic agents by fractionating its stem bark using different solvents.

\section{Materials and Methods}

\section{Plant materials and authentication}

Fresh stem barks of Mangifera indica were obtained from University of Ilorin, Kwara State, Nigeria. Authentication of the plant was done in the Department of Plant Biology, University of Ilorin, Ilorin, Nigeria where voucher specimen was deposited at the University herbarium with voucher number UIH 1080.

\section{Laboratory animals}

Forty (40) albino rats (Rattus norvegicus) of both sexes with an average weight of $50.0 \mathrm{~g} \pm 10.0 \mathrm{~g}$ were used for this study. The animals were obtained from the animal house in the Department of Biochemistry, University of Ilorin. They were housed in cages under standard conditions $\left(25-29^{\circ} \mathrm{C}, 12\right.$ hour light and 12 hour darkness cycles) and fed rat chow. They were also given water ad libitum. This study was conducted in accordance with the ethics of animal experimentation of the Department of Biochemistry, University of Ilorin.

\section{Feed materials}

Yellow maize (Zea may) and locust bean [Parkia biglobosa (A.) Jacq] seeds were obtained from local sellers at Oja Oba Market, Ilorin, Nigeria; the vegetable oil used was a product of Grand Cereals and Oil Mills Limited, Bukuru, Jos, Nigeria. The vitamin mix was a product of BASF Aktiengesellschaft, Germany Pantex, Holland. Component chemicals of the mineral mix used were products of Sigma Chemical Company Limited, London.

\section{Other reagents}

All other reagents used were of analytical grade and were prepared in all glass wares, and stored in reagent bottles. Distilled water was obtained from the Department of Biochemistry, University of Ilorin.

\section{Preparation of plant extract}

The ethanolic extract of the stem bark of the plant was prepared according to modified methods reported by Harborne and Sofowora $[13,14]$. The plant samples were collected, air dried and pulverized at Oja Oba Market, Ilorin, Nigeria. The powdered material was then extracted using ethanol for 72 hours. The extract was concentrated to dryness and a brownish gummy extract was obtained. The residue was further extracted using hexane and ethyl acetate and concentrated to dryness with a rotary evaporator. The residues obtained were then transferred into pre-weighed sample containers and later used for the study.

\section{Phytochemical screening}

The solvent $n$-hexane, ethyl acetate and ethanolic fractions of the extract were screened for phytochemicals using standard procedures:

The presence of alkaloids and phlobatannins were determined according to the method described by Harborne [13] while the method described by Odebiyi and Sofowora [15] was used for flavonoids and tannins. Steroids and phenolics were qualitatively determined by the method of Trease and Evans [16] while glycosides and saponins were determined by the method of Wall et al. [17].

\section{Feed formulation}

The method adopted for the formulation of iron sufficient and iron deficient feed was that of Folayan [18] as modified by Oladiji et al. [19]. In this method, locust bean seeds were used as the source of protein, among other things. The components of the diets were thoroughly mixed and made into pellets to ensure good handling by the animals. It was produced weekly and packed into air-tight polythene bags to prevent rancidity, auto-oxidation of the oil and microbial contamination (Table 1).

Table 1: Feed Components of Iron Sufficient and Iron Deficient Diets.

\begin{tabular}{|l|l|l|}
\hline Feed Components & Iron Sufficient $\mathbf{( g / k g )}$ & Iron Deficient $\mathbf{( g / k g )}$ \\
\hline Locust bean seed & 750 & 750 \\
\hline Maize flour & 40 & 40 \\
\hline Corn husk & 20 & 20 \\
\hline Soybean oil & 40 & 40 \\
\hline Sucrose & 100 & 100 \\
\hline Methionine & 5 & 5 \\
\hline Lysine & 5 & 5 \\
\hline Mineral mix & 30 & 30 \\
\hline Vitamin mix & 10 & 10 \\
\hline FeSO4·7H20 & $35.06 \mathrm{mg} / \mathrm{kg}$ & $8.50 \mathrm{mg} / \mathrm{kg}$ \\
\hline
\end{tabular}

aVitamin mix (per kg of diet): vitamin A, 100,000 IU; vitamin D3, 10,000 IU; vitamin E, $100 \mathrm{mg}$; vitamin B1, 20mg; vitamin B2, 40mg; d-calcium pantothenate, $100 \mathrm{mg}$; vitamin B6, $15 \mathrm{mg}$; vitamin C, $250 \mathrm{mg}$; vitamin K3, $15 \mathrm{mg}$; folic acid, $5000 \mathrm{mcg}$; nicotinic acid, $200 \mathrm{mg}$; biotin, 150mcg; inositol, $80 \mathrm{mg}$.

${ }^{b}$ Mineral mix $(\mathrm{g} / \mathrm{kg})$ : $\mathrm{CoCl}_{2} \cdot 6 \mathrm{H}_{2} \mathrm{O}(0.001), \mathrm{CuSO}_{4} \cdot 5 \mathrm{H}_{2} \mathrm{O}(0.079)$, $\mathrm{MnSO}_{4} \cdot 7 \mathrm{H}_{2} \mathrm{O}(0.178), \mathrm{KI}(0.032), \mathrm{NaCl}(3.573), \mathrm{ZnCO}_{3}(1.60), \mathrm{CaSO}_{4}$ (11.610), $\mathrm{MgSO}_{4} \cdot 7 \mathrm{H}_{2} \mathrm{O}$ (2.292), $\mathrm{K}_{2} \mathrm{HPO}_{4}(10.559)$.

\section{Animal grouping and experimental design}

Forty (40) animals were housed in metabolic cages of dimensions $33 \mathrm{~cm} \times 20.5 \mathrm{~cm} \times 19 \mathrm{~cm}$ under standard conditions (12-hr light: 12 -hr dark cycle; $28^{\circ} \mathrm{C} \pm 3{ }^{\circ} \mathrm{C}$ and $40-55 \%$ humidity). They were allowed free access to normal rat chow and distilled water. They were acclimatized for seven days before the start of the experiment. After acclimatization, they were fasted 
for 24 hours (food except water was removed) prior to the commencement of the experiment.

The animal grouping consisted of an initial three groups:

a) A-10 Rats maintained on iron sufficient diet designated as IS.

b) B - 25 Rats maintained on iron deficient diet designated as ID.

c) C - 5 Rats maintained on commercial feed and designated CF.

Animals in groups A and B were maintained on their respective diets for eight (8) weeks. This was to induce iron deficiency anaemia in the animals in group B, and verify with the animals in group A which had sufficient iron in their diet. At the end of the eight (8) weeks feeding period, five (5) rats each from IS and ID groups were sacrificed and their haematological indices were determined. Upon the confirmation of the anaemic state of the ID animals, the remaining rats in group B were further grouped into four (4), with five (5) rats in each group. One of these groups was maintained on the iron deficient feed for two weeks without treatment. The remaining three (3) groups were orally treated with ethyl acetate (EA), n-hexane $(\mathrm{NH})$ and ethanolic (ET) fractions of the $M$. indica stem bark extract daily, for two (2) weeks. The grouping was as follows:

a) B1- Iron deficient rats fed with iron deficient feed for two weeks (iron deficient feed all through) designated IDF

b) B2- Iron deficient rats orally treated with ethyl acetate fraction of the extract for two weeks designated as EA

c) B3- Iron deficient rats orally administered on a daily basis for two weeks with n-hexane fraction of the extract designated $\mathrm{NH}$

d) B4- Iron deficient rats orally served ethanolic fraction daily for two weeks designated ET.

The extracts were administered to the animals in the various groups using oro-pharyngeal cannula. They were sacrificed after the second week of extract administration.

\section{Haematological parameters}

The following haematological parameters were analysed using automated hematologic analyzer: haemoglobin, packed cell volume, red blood cells, employing the methods of Dacie and Lewis [20].

\section{Determinaton of Serum Ferritin}

The principle employed is based on enzyme-based immunosorbent assay (ELISA). The results were read with a micro plate reader.

\section{Statistical Analysis}

Values obtained were expressed as \pm standard error of mean (SEM). The values were subjected to Analysis of Variance (ANOVA), as well as Duncan's multiple Range Test, to determine statistical significance. Differences were considered significant at $\mathrm{P}<0.05$.

\section{Results}

\section{Haematological parameters of experimental animals}

Feeding of the negative control group( ID) with an iron deficient feed for eight weeks led to a significant decrease $(\mathrm{P}>0.05)$ in the packed cell volume(PCV), platelet and red blood cell(RBC) when compared to the iron sufficient (positive control) group as observed in Table 2. It was observed that upon subsequent administration of the solvent extracts of the plant to the iron deficient animals, there was an increase $(\mathrm{P}<0.05)$ in the haematological parameters of the animals in the groups given the extract when compared with the iron deficient (negative control) group. There was no significant difference $(\mathrm{P}>0.05)$ in the mean cell haemoglobin $(\mathrm{MCH})$ and the mean cell haemoglobin concentration (MCHC) between the treated groups and the positive control groups, no significant difference in the white blood cell of all the groups as shown in Table 3.

Table 2: Haematological Parameters of Experimental Animals as at 8th Week.

\begin{tabular}{|c|c|c|c|}
\hline Groups & PCV (\%) & $\begin{array}{c}\text { WBC(106cells/m } \\
\mathbf{m}^{\mathbf{3}} \mathbf{)}\end{array}$ & $\begin{array}{c}\mathbf{R B C}(\mathbf{1 0 6} \text { cells } / \mathbf{m} \\
\left.\mathbf{m}^{3}\right)\end{array}$ \\
\hline IS & $44.40 \pm 1.62 \mathrm{~b}$ & $14.60 \pm 4.99^{\mathrm{a}}$ & $8.01 \pm 0.29^{\mathrm{b}}$ \\
\hline ID & $38.85 \pm 1.13 \mathrm{a}$ & $17.65 \pm 0.84^{\mathrm{a}}$ & $6.68 \pm 0.17^{\mathrm{a}}$ \\
\hline
\end{tabular}

Values carrying different superscripts $(a-b)$ down the group for each parameter are significantly different $(p<0.05), n=5$ replicates \pm S.E. PCV: packed cell volume; WBC: white blood cell; RBC: red blood cell; IS:(iron sufficient feed fed rats); ID:(iron deficient feed fed rats).

Table 3: Haematological Parameters of Experimental Animals After Administration of the Extracts.

\begin{tabular}{|c|c|c|c|c|c|}
\hline Groups & PCV(\%) & WBC & $\begin{array}{c}\text { MCHC (g/ } \\
\mathbf{d L})\end{array}$ & MCV(fL) & MCH \\
\hline IS & $\begin{array}{c}47.93 \pm \\
1.07^{\mathrm{c}}\end{array}$ & $\begin{array}{c}14.26 \\
\pm 1.6^{\mathrm{a}, \mathrm{b}}\end{array}$ & $\begin{array}{c}27.60 \\
\pm 0.29^{\mathrm{a}}\end{array}$ & $\begin{array}{c}60.76 \\
\pm 0.64^{\mathrm{a}}\end{array}$ & $\begin{array}{c}16.78 \\
\pm 0.23^{\mathrm{a}}\end{array}$ \\
\hline ID & $\begin{array}{c}17.73 \\
\pm 0.73^{\mathrm{a}}\end{array}$ & $\begin{array}{c}17.03 \\
\pm 6.43^{\mathrm{a}, \mathrm{b}}\end{array}$ & $\begin{array}{c}65.83 \\
\pm 15.96^{\mathrm{b}}\end{array}$ & $\begin{array}{c}78.50 \\
\pm 1.60^{\mathrm{b}}\end{array}$ & $\begin{array}{c}51.16 \\
\pm 11.7^{\mathrm{b}}\end{array}$ \\
\hline CF & $\begin{array}{c}45.74 \\
\pm 0.92^{\mathrm{b}, \mathrm{c}}\end{array}$ & $\begin{array}{c}15.64 \\
\pm 2.42^{\mathrm{a}, \mathrm{b}}\end{array}$ & $\begin{array}{c}29.16 \\
\pm 0.83^{\mathrm{a}}\end{array}$ & $\begin{array}{c}61.00 \\
\pm 2.48^{\mathrm{a}}\end{array}$ & $\begin{array}{c}17.70 \\
\pm 0.30^{\mathrm{a}}\end{array}$ \\
\hline EA & $\begin{array}{c}42.27 \\
\pm 0.74^{\mathrm{b}, \mathrm{c}}\end{array}$ & $\begin{array}{c}16.95 \\
\pm 2.21^{\mathrm{a}, \mathrm{b}}\end{array}$ & $\begin{array}{c}27.57 \\
\pm 0.34^{\mathrm{a}}\end{array}$ & $\begin{array}{c}64.30 \\
\pm 0.89^{\mathrm{b}}\end{array}$ & $\begin{array}{c}17.72 \\
\pm 0.19^{\mathrm{a}}\end{array}$ \\
\hline NH & $\begin{array}{c}43.47 \\
\pm 2.82^{\mathrm{b}, \mathrm{c}}\end{array}$ & $\begin{array}{c}23.20 \\
\pm 5.81^{\mathrm{b}, \mathrm{c}}\end{array}$ & $\begin{array}{c}27.72 \\
\pm 0.34^{\mathrm{a}}\end{array}$ & $\begin{array}{c}62.87 \\
\pm 1.53^{\mathrm{a}, \mathrm{b}}\end{array}$ & $\begin{array}{c}17.40 \\
\pm 0.21^{\mathrm{a}}\end{array}$ \\
\hline ET & $\begin{array}{c}42.86 \\
\pm 0.50^{\mathrm{b}}\end{array}$ & $\begin{array}{c}23.60 \\
\pm 2.75^{\mathrm{b}, \mathrm{c}}\end{array}$ & $\begin{array}{c}27.96 \\
\pm 0.21^{\mathrm{a}}\end{array}$ & $\begin{array}{c}58.56 \\
\pm 0.84^{\mathrm{a}}\end{array}$ & $\begin{array}{c}16.40 \\
\pm 0.34^{\mathrm{a}}\end{array}$ \\
\hline
\end{tabular}

Values carrying different superscripts $(a-c)$ down the group for each parameter are significantly different $(p<0.05), n=5$ replicates \pm S.E. PCV: packed cell volume; WBC: white blood cell; MCV: mean corpuscular volume; $\mathrm{MCH}$ : mean cell haemoglobin; $\mathrm{MCHC}$ : mean cell haemoglobin cell; IS:(iron sufficient feed fed rats); ID:(iron deficient feed fed rats); CF: (rats fed with commercially sold feed),EA: (rats administered with ethyl acetate fraction of Mangifera indica + iron deficient feed); $\mathrm{NH}$ : (rats administered with $\mathrm{n}$-hexane fraction of Mangifera indica + iron deficient feed);ET: (rats administered with ethanolic fraction of Mangifera indica + iron deficient feed). 


\section{Serum ferritin level in experimental animals}

A significant decrease $(\mathrm{P}>0.05)$ was noticed in the iron deficient group when compared to the positive (iron sufficient) control group. On administration of the extracts to the animals, the serum ferritin level of the treated groups compared favourably with the iron sufficient control group (Figure 1).

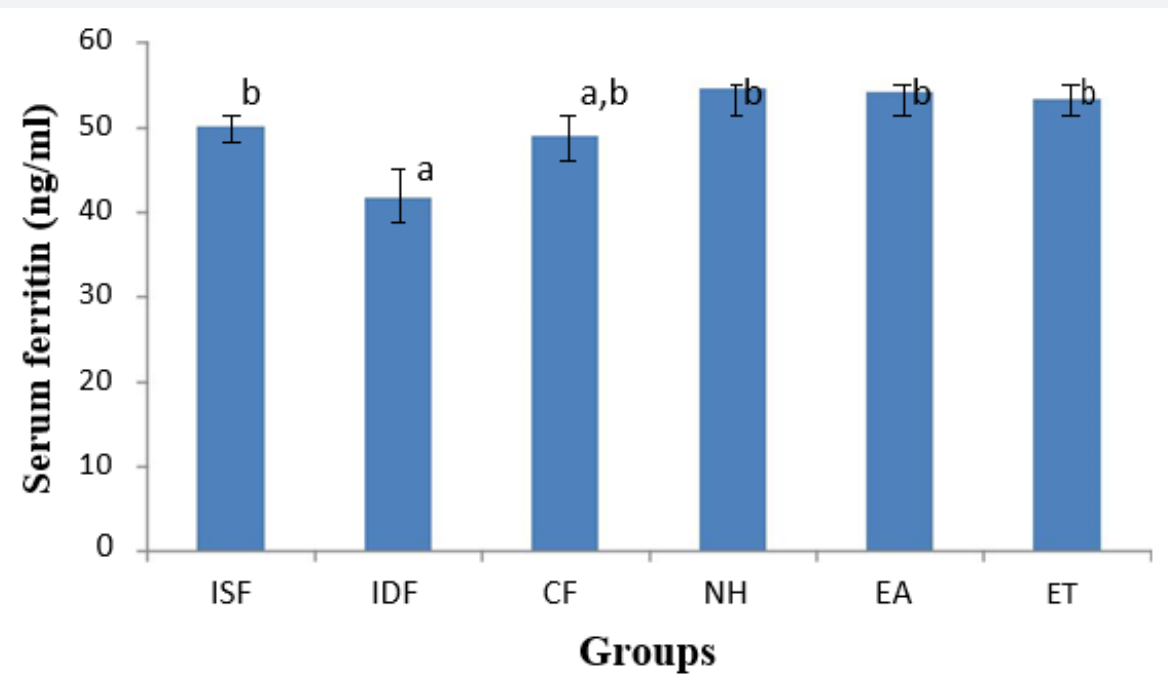

ISF: iron sufficient fed rats; IDF: iron deficient fed rats; CF: (rats fed with commercially sold feed), EA :(rats administered with ethyl acetate fraction of Mangifera indica + iron deficient feed); $\mathrm{NH}$ :(rats administered with n-hexane fraction of Mangifera indica + iron deficient feed); ET:(rats administered with ethanolic fraction of Mangifera indica + iron deficient feed).

Figure 1: Serum Ferritin Level in Experimental Animals.

\section{Phytochemical screening for various extracted fractions of mangifera indica}

The phytochemical screening carried out shows that saponin was the only phytochemical present in the three solvent extracts as shown in Table.

Table 4: Phytochemical Screening for Various Extracted Fractions of Mangifera indica.

\begin{tabular}{|c|c|c|c|}
\hline Test/sample & N -hexane & Ethanol & Ethyl acetate \\
\hline Saponins & + & + & + \\
\hline Tannins & - & + & + \\
\hline Flavonoids & + & - & - \\
\hline Glycosides & + & + & - \\
\hline Steroids & - & - & - \\
\hline Phlobatannins & - & + & + \\
\hline Terpenoids & - & + & - \\
\hline Alkaloids & - & - & - \\
\hline Anthraquinones & - & - & - \\
\hline
\end{tabular}

+ Means present while - means phytochemical is absent.

\section{Discussion}

The modified method described by Oladiji et al. [19] used resulted in a significant reduction $(\mathrm{P}<0.05)$ in the haematological parameters in the rats as the values for PCV and RBC were lower for the iron deficient group as compared to the iron sufficient group. The significant decrease in haemoglobin, PCV and RBC levels of iron deficient rats may be attributed to onset of iron deficiency anaemia when rats were placed on iron-deficient diet [19].
It was reported that $1 \mathrm{ml}$ of Mangifera indica L. stem bark extract administered to adult albino rats for 2 weeks increased the haematological parameters of the rats [10], also Modupe and Oladiji [21] reported a dose dependent increase of mangifera indica aqueous stem bark extract with the highest dose been $75 \mathrm{mg} / \mathrm{kg}$ body weight, this report informed the use of $75 \mathrm{mg} / \mathrm{kg}$ body weight for this study. On administration of $1 \mathrm{ml}(75 \mathrm{mg} / \mathrm{kg}$ body weight) of the $\mathrm{N}$-hexane, ethyl acetate and ethanolic fractions of the Mangifera indica stem bark extract, the PCV increased in the test groups $(\mathrm{P}>0.05)$ and compared favourably with the positive and negative control groups [22]. This corroborates the reports of previous studies which suggests that Mangifera indica stem bark has hematopoietic activity and increases resistance to oxidative damage of the red blood cell membranes [4] . The significant increase $(\mathrm{P}>0.05)$ in the mean cell volume of the iron deficient group which showed the presence of anaemia, confirmed the previous study by Eteng et al. [23]. In the study, the increased mean cell volume was linked with megaloblastic anaemia and chronic haemolytic anaemia. The increases in mean cell haemoglobin in the deficient group may be an indication of certain degree of intravascular haemolysis as also reported by Criswell [24]. The significant decrease $(\mathrm{P}<0.05)$ in the mean cell haemoglobin of the animals treated with the plant extract may be an indication of the ability of the plant to revert the haemolysis in iron deficient animals. The plant may hence be suggested to prevent and treat red blood cell lysis. This is supported by the studies carried out on another hematopoietic plant [25].

Several studies have been carried out on the stem bark of Mangifera indica but none has reported the bioactive agent 
responsible for its action. Although it has been suggested that the phytochemicals present in the stem bark might be responsible for its hematopoietic action there is no experimental data to back up this assumption. The fractionation of the extract based on solubility of phytochemicals in different solvent was to elucidate the possible phytochemical responsible for its anti-anaemic property [26]. The phytochemical analysis of the different fractions of Mangifera indica stem bark showed the presence of saponins in the three fractions and these three fractions were able to reverse the anti-anaemic condition of experimental animals, this findings also confirms the study by Modupe and Oladiji [21] that saponin and glycoside was found present in the plant extract. In this study, glycoside was only observed in two of the fractions (hexane and ethanolic fractions). Since the reversal effect was noticed in the three fractions, it implicates saponins from medicinal plants to be playing a role in haematopoiesis. This agrees with previous studies which reported that the presence of saponins, phenolics and glycosides in some plant extract may be responsible for the acclaimed anti-anaemic potential of the plants. Saponins are known to enhance natural resistance and recuperative powers of the body [27], and inhibit platelet aggregation and thrombosis [19]. Although saponins have been reported to lyse the red blood cells but result from this study shows otherwise and agrees with Modupe and Oladiji [21].

Saponins have been reported to be an antioxidant and nonhaem iron is better absorbed in the presence of an antioxidant which prevents the formation of insoluble and non -absorbable iron compounds, and enhances the reduction of ferric iron to ferrous iron, the form in which iron is absorbed by the mucosal cells. Therefore, the saponin present in the plant extract might be responsible for the increase in absorption of the non-haem form of iron found in the plant and neutralization of free radicals at cellular level which may have accounted for the decrease in the mean cell haemoglobin as there will be reduction in the amount of red blood cells lysed by the radicals. Saponins are known to be membrane active agents, surfactants and also amphipathic in nature [28]. Due to its nature, it can penetrate membranes since it has both hydrophilic and lipophilic parts, it is therefore suggested that it might also be facilitating the transport of ferrous iron across membranes thereby increasing its absorption by facilitating iron diffusion across membranes of cells. One may therefore hypothesize that saponins may be aiding in the diffusion of iron across membranes thereby increasing its uptake in the mucosal cells.

Ferritin is a protein in the body that binds to iron and serves as the storage form of iron, it stores iron in non-toxic form and transports it to areas where they are required. According to Figure 1, the serum ferritin of the iron deficient group decreased significantly $(\mathrm{P}<0.05)$ compared to the control groups. The iron deficient group had a low serum ferritin level since iron can only be stored when it is in excess quantity in the blood but the stores are depleted in case of deficiency as the body would need enough iron to carry out biological processes. Low serum ferritin level can be a confirmation of the lack of iron in the body which leads to iron deficiency anaemia.

However, the serum ferritin level of the group treated with the extracts increased significantly $(\mathrm{P}>0.05)$ and compared favourably with the iron sufficient control group. Ferritin protein has several functions in the body for example; mitochondrial ferritin has several molecular functions which includes ferroxidase activity responsible for reduction in free radical formation, oxidoreductase activity across membranes and cellular iron homeostasis. Therefore, a decrease in the ferritin level will affect all functions associated with ferritin which includes conversion of iron from ferrous state to ferric state and the release of this toxic form of iron leads to formation of free radicals. Increase in serum ferritin level can either be due to an increase in iron stores or an infection. However, infection may not be the case in this study due to no significant difference noticed in the white blood cell of any of the groups. Therefore, the significant increase noticed in the groups administered with the extracts may be attributed to an increase in the iron stores.

\section{Conclusion}

The hematopoietic property of Mangifera indica extract fractions may therefore be suggested to be attributed to the bioactive agents found in the plant, data obtained from this studies suggest that saponin may be responsible for the haematopoietic activity of Mangifera indica either by acting as a transporter for aiding iron transport across the membrane or as an antioxidant by making iron available in the ferrous form for easy absorption. Further studies should therefore include bioactivity guided fractionation, isolation of saponins from Mangifera indica and its characterization in order to have a better understanding of its mechanism of action.

\section{References}

1. Wang J, Pantopoulos K (2011) Review article: Regulation of cellular iron metabolism. Biochemistry Journal 434(3): 365-381.

2. Maureen M Black (2003) Micronutrient Deficiencies and Cognitive Functioning. J Nutr 133: 3927S- 3931S.

3. Reid R, Burt A, Harrison D, David J, Levison DA, et al. (2008) Muir's textbook of pathalogy. (14th ed.). Hodder Education, United Kingdom.

4. Ogbe RJ, Adoga GI, Abu AH (2010) Anti-anaemia potentials of some plant extracts on phenyl hydrazine induced anaemia in rabbits. Journal of Medicinal Plants Research 4(8): 680-684.

5. Crawley J (2004) Reducing the burden of anemia in infants and young children in malaria-endemic countries of Africa: from evidence to action. Am J Trop Med Hyg 71(suppl 2): 25-34.

6. de Benoist B, McLean E, Egli I, Cogswell M (2008) Worldwide prevalence of anaemia 1993-2005- WHO Global Database on Anaemia. WHO-CDC; $48 \mathrm{p}$.

7. Jacob RA, Sandstead HH, Klevay LM, Johnson LK (1980) Utility of serum ferritin as a measure of iron deficiency in normal males undergoing repetitive phlebotomy. American Society of Hematology 56(5): 786791

8. Ekpe ED, Ebana RVB, Madunagu BE (1990) Antimicrobial activity of four medicinal plants on pathogenic Bacteria and phytopathogenic fungi. West Af J Biol Appl'd Chem 35: 2-5. 
9. Edeoga HO, Okwu DE, Mbaebie BO (2005) Phytochemical constituents of some Nigerian medicinal plants. Afr J Biotechnol 4(7): 685-688.

10. Nwinuka NM, Monanu MO, Nwiloh BI (2008) Effects of aqueous extract of Mangifera indica L. (Mango) stem bark on haematological parameters of normal albino rats. Pak J Nutr 7(5): 663-666.

11. Muruganandan K, Srinivasan S, Gupta PK, Gupta JL (2005) Effect of mangiferin on hyperglycemia and atherogenicityin streptozotocin diabetic rats. J Ethnopharmacol 93: 497-501.

12. Ojewole J (2005) Anti-inflammatory, analgesic and hypoglycemic effects of Mangifera indica Linn. (Anacardiaceae) stem-bark aqueous extract. Methods Find Exp Clin Pharmacol 27: 547-54.

13. Harborne JB (1973) Phytochemical Methods: A Guide to Modern Techniques of Plant Analysis. Chapman \& Hall, London, pp. 279.

14. Sofowora A (1982) Medicinal Plants and Traditional Medicine in Africa. John Willey and Sons, pp: 142-146.

15. Odebiyi A, Sofowora AE (1978) Phytochemical screening of Nigerian Medicinal Plants. Part III. Lloydia 41(3): 234-246.

16. Trease GE, Evans WC (1989) A Textbook of Pharmacognosy, 13th ed. Bailliere-Tindall Ltd, London.

17. Wall ME, Krider MM, Krewson CF, Eddy CR, Wiliaman JJ, et al. (1954) Steroidal sapogeninins XIII. Supplementary table of data for steroidal sapogenins VII. Agricultural Research Service Circular 363, 17.

18. Folayan AT (1997) Status of some energy - linked and membrane -bound enzyme activities in selected tissues of rats fed iron and essential fatty acid deficient diets. (Ph.D Theses).

19. Oladiji AT, Jacob TO, Yakubu MT (2007) Anti-anaemic potentials of aqueous extract of Sorghum bicolor

(L) moench stem bark in rats. Journal of Ethnopharmacology 3(3): 651656

This work is licensed under Creative

Commons Attribution 4.0 License

DOI: 10.19080/JCMAH.2018.06.555698
20. Dacie JV, Lewis SM (1991) Practical Haematology. Churchill Livingstone. Edinburgh. Seventh edition. Pp 521-534.

21. Modupe 0, Oladiji AT (2015) Optimizing dose of aqueous extract of Mangifera indica L stem bark for treating anaemia and its effect on some disaccharidases activity in iron deficient weanling rats. Journal of Nutrition and Intermediary Metabolism 3: 18-22.

22. Ogbe, Raphael John, Adenkola, Adeshina Yahaya, Anefu, et al. (2012) Aqueous Ethanolic Extract of Mangifera indica Stem Bark Effect on the Biochemical and Haematological Parameters of Albino Rats. Arch. Appl Sci Res 4(4): 1618-1622.

23. Eteng MU, Ebong PE, Ettarh RR, Umoh IB (1998) Aminotransferase activity in serum, liver and heart tissue of rats exposed to theobromine. Indian Journal of Pharmacology 30: 339-342.

24. Criswell KA, Sulkanen AP, Hochbaum AF, Bleavins MR (2000) J Appl Toxicol 20: 25 -34.

25. Ndem JI, Otitoju O, Akpanaiabiatu MI, Uboh FE, Uwah AF, et al. (2013) Haematoprotective property of Eremomastax Speciosa (Hochst.) on experimentally induced anaemic wistar rats. Annals of Biological Research 4(6): 356-360.

26. Gbadamosi IT, Moody JO, Yekin AO (2012) Nutritional Composition of Ten Ethnobotanicals Used for the Treatment of Anaemia in Southwest Nigeria. European Journal of Medicinal Plants 2(2): 140-150.

27. Singh N, Verma P, Mishara N, Nath R (1991) A complete evaluation of some anti stress agents of plants origin. Indian Journal of Pharmcology 2: 21-99.

28. Negi JS, Negi PS, Pant GJ, Rawat MSM, Negi SK (2013) Naturally occurring saponins: Chemistry and Biology. Journal of poisonous and Medicinal Plant Research 1(1): 006-011.

\section{Your next submission with Juniper Publishers} will reach you the below assets

- Quality Editorial service

- Swift Peer Review

- Reprints availability

- E-prints Service

- Manuscript Podcast for convenient understanding

- Global attainment for your research

- Manuscript accessibility in different formats

( Pdf, E-pub, Full Text, Audio)

- Unceasing customer service

Track the below URL for one-step submission

https://juniperpublishers.com/online-submission.php 